\title{
Synthesis and Characterization of Nano-doped Zinc Oxide and its Application as Protective Oxidative Changes in the Retina of Diabetic Rats
}

\section{Soheir N Abd El-Rahman ${ }^{1 *}$, Reda SM² and Sheikha M AIGhannam ${ }^{3}$}

${ }^{1}$ College of Science, University of Dammam, Agriculture Research Center, Giza, Saudi Arabia

${ }^{2}$ Chemistry Department, Benha University, Benha, Egypt

${ }^{3}$ College of Science, University of Dammam, Saudi Arabia

\begin{abstract}
Oxidative stress is a basic mechanism behind the development of diabetic retinopathy (DR). Therefore, the present study conducted to evaluate the protective effect of zinc oxide nanoparticles (ZnONPs) doped with fluorine $(\mathrm{F}: \mathrm{ZnO})$ and chlorine $(\mathrm{Cl}: \mathrm{ZnO})$, on retinal oxidative stress in type II diabetic rats. TEM showed that the $\mathrm{F}: \mathrm{ZnO}$ and $\mathrm{Cl}: \mathrm{ZnO}$ have average particle size 17.7 and $59.3 \mathrm{~nm}$, respectively. The results indicated that serum glucose was increased significantly $(p \leq 0.05)$ and serum insulin was decreased significantly 3 days after treatment with STZ compared to other groups. STZ treatment depleted both retinal and liver TBA and retinal GST contents. While, simultaneous treatment rats with low and high dose of STZ + F:ZnO and STZ + $\mathrm{Cl}: \mathrm{ZnO}$ were decreased serum glucose induced by STZ and reversed the deplete influence on GSH level of retinal and reduced the highs in TBA levels of livers and retinas in STZ -administrated rats. The results investigate the useful effects of high dose of F:ZnO and $\mathrm{Cl}: \mathrm{ZnO}$ in protection diabetic rats against hyperglycemia and retina against oxidative stress.
\end{abstract}

Keywords: Nano-doped zinc oxide; Oxidative stress; F:ZnO; $\mathrm{Cl}: \mathrm{ZnO}$; Diabetic retinopathy

\section{Introduction}

All over the world there are a large number of people suffer from diabetes. Diabetes mellitus, is a result of metabolic diseases and causes high blood sugar in person, either because the body does not produce enough insulin, or because cells do not respond to the insulin that is produced [1]. Therefore, diabetes mellitus patients would require and several development medications with multiple modes of actions.

Retinopathy is a severely disabling complication of diabetes, however, the biochemical or cellular links between elevated blood glucose levels, and the vascular lesions remain incompletely understood. Understanding of the pathological mechanisms underlying these lesions is paramount to ultimately developing therapeutic interventions. The development of diabetic vascular complications begins with prolonged hyperglycemia, which results in expression of factors which activates the $\mathrm{g} 2$ isoform of protein kinase $\mathrm{C}$ and stimulate vascular endothelial proliferation and increased capillary permeability [2]. Other mechanisms may also be involved such as increased glucose metabolism via the polyol pathway (aldose reductase), sorbitol is produced via this pathway in possibly toxic concentrations [3]. The high levels of glucose are able to induce non enzymatic glycation of proteins [4-7]. The accumulation of advanced glycation end products contribute to the thickening of basement membranes, as well as several other abnormalities in tissues, especially endothelium [8]. Several studies reported that oxidative stress an integral and possibly causative part of the pathogenesis of diabetic retinopathy [9-14]. A rational extension of this proposed role for oxidative stress is the suggestion that the different susceptibility of diabetic patients to microvascular and macrovascular complications may be a function of the endogenous antioxidant status. Thus, antioxidant therapy may be a suitable approach to determine the roles of intrinsic retinal abnormalities in the development of diabetic retinopathy [11].

Nano- $\mathrm{ZnO}$ is a new product whose particle diameter is between 1 to $100 \mathrm{~nm}$. More recently, the study of $\mathrm{ZnO}$ nanoparticles is a very active area because their properties can be tuned according to the desired application [15-17]. As a semiconductor, $\mathrm{ZnO}$ has a wide direct band gap $(\mathrm{Eg}=3.37 \mathrm{eV})$, with a large excitonic binding energy of $60 \mathrm{meV}$. Additionally, it is a non-central symmetry material, and exhibits biocompatibility properties. All of these properties make $\mathrm{ZnO}$ an important functional oxide. Due to its fast electron transfer capability, $\mathrm{ZnO}$ is a key material for fabrication of biomembranes, and enzymatic detective devices [18]. Nano-zinc oxide is a key element for maintenance of the structural and functional integrity of eukaryotic cells and tissues [19]. Many studies have addressed the importance of $\mathrm{ZnO}$ as an antioxidant and a therapeutic agent in several free radicals initiating systems [2024] reported the antidiabetic effects of ZnONPs through induction of insulin, IR and glucose metabolizing enzymes gene expression. In the same line Umrani and Paknikar, [25] proved the ability of ZnONPs for controlling of blood glucose in diabetic rats, these are only two studies that monitored the effect of $\mathrm{ZnONPs}$ on diabetic rats, but there is not previous study carried out with $\mathrm{F}: \mathrm{ZnO}$ and $\mathrm{Cl}: \mathrm{ZnO}$ nanoparticles on diabetic rats. Therefore, this work was designed to $I$. increase the carrier concentration and modify the optical properties of $\mathrm{ZnO}$ nanoparticles, the fluorine and chlorine doping. II. investigate the ability of $\mathrm{F}: \mathrm{ZnO}$ and $\mathrm{Cl}: \mathrm{ZnO}$ to modulates blood glucose, TBA (MDA), GSH and insulin levels in the STZ diabetic rats. III. provide further insights into roles of zinc in diabetes and diabetic retinopathy, which may help set a new direction toward the development of effective treatments.

*Corresponding author: Soheir N Abd El-Rahman, College of Science University of Dammam, Agriculture Research Center, Giza, Saudi Arabia, Tel: +966533687730; E-mail: soheirkenawy@yahoo.com/skenawy@uod.edu.sa

Received June 20, 2016; Accepted July 23, 2016; Published July 28, 2016

Citation: El-Rahman SNA, Reda SM, AIGhannam SM (2016) Synthesis and Characterization of Nano-doped Zinc Oxide and its Application as Protective Oxidative Changes in the Retina of Diabetic Rats. J Diabetes Metab 7: 691. doi: 10.4172/2155-6156.1000691

Copyright: () 2016 El-Rahman SNA, et al. This is an open-access article distributed under the terms of the Creative Commons Attribution License, which permits unrestricted use, distribution, and reproduction in any medium, provided the original author and source are credited. 
Citation: El-Rahman SNA, Reda SM, AIGhannam SM (2016) Synthesis and Characterization of Nano-doped Zinc Oxide and its Application as Protective Oxidative Changes in the Retina of Diabetic Rats. J Diabetes Metab 7: 691. doi: 10.4172/2155-6156.1000691

\section{Materials and Methods}

\section{Experimental}

The $\mathrm{ZnO}$ nanoparticles doped with fluorine was prepared by a chemical solution method from zinc acetate $(\mathrm{ZnAc})$ and oxalic acid. The preparation is as follows: $20 \mathrm{~mL}$ of a $0.5 \mathrm{M}$ ethanolic solution of oxalic acid was added drop-by-drop to $20 \mathrm{~mL}$ of a $0.1 \mathrm{M}$ ethanolic solution of $\mathrm{ZnAc}$ under stirring and maintained at $60^{\circ} \mathrm{C}$ for $3 \mathrm{~h}$. Then $0.5 \mathrm{M}$ of aqueous solution of ammonium fluoride was added to the above solution in order to get at $5 \% \mathrm{~F} / \mathrm{Zn}$ ratio. A white precipitate was obtained, which was separated by filtration and washed with a mixture of 75:25 water: ethanol. This precipitate was dried in an oven at a temperature of $100^{\circ} \mathrm{C}$ for $24 \mathrm{~h}$. The obtained precursor was finally calcined at $500^{\circ} \mathrm{C}$ for $2 \mathrm{~h}$, with a heating rate of $5^{\circ} \mathrm{C} / \mathrm{min}$.

For the preparation of $\mathrm{Cl}$-doped $\mathrm{ZnO}$ nanoparticles, the procedure was the same; however, an aqueous solution of ammonium chloride $\left(\mathrm{NH}_{4} \mathrm{Cl}\right) 0.5 \mathrm{M}$ was added to the $\mathrm{ZnAc}$ solution.

All the reagents used in the experiments were of analytical grade and used directly as purchased.

\section{Characterization}

The structure was analyzed by FTIR spectra (FTIRNicolet6700). $\mathrm{X}$-ray powder diffractometer (D/max r-B, Rigaku, Japan) was employed to assess the crystallinity. Surface Morphology was analyzed by SEM (Quanta 3D FEG/ FEI) and TEM (JEOL, Tokyo, Japan) operating at 60 $\mathrm{kV}$. The surface properties namely BET surface area was determined using conventional apparatus.

\section{Biological methods}

Male albino adult rats (105 animals weighing $200 \mathrm{~g} \pm 50$ ) were obtained from the private market, Helwan, Giza, Egypt, then transported to Animal House of Ophthalmology Research Institute, Giza, Egypt. Rats were housed in individual cages with screen bottoms and fed on basal diet (corn starch $70 \%$, casein $10 \%$, corn seed oil $10 \%$, cellulose $5 \%$, salt mixture $4 \%$ and vitamins mixture $1 \%$ ) for ten days. After equilibration, rats were weighted and divided into six groups (fifteen animals per each) everyone was assigned to one of the six diet groups (G1: Negative Control (NC), G2: STZ-treated group that received a single ip dose of STZ (60 mg/kg b.w), G3:treated with STZ $(60 \mathrm{mg} / \mathrm{kg} \mathrm{b.w})+$ single daily oral low dose of F: $\mathrm{ZnO}(5 \mathrm{mg} / \mathrm{kg} \mathrm{b.w})$, G4:treated with STZ $(60 \mathrm{mg} / \mathrm{kg}$ b.w $)+$ single daily oral high dose of F:ZnO (10 mg/kg b.w), G5:treated with STZ (60 mg/kg b.w)+ single daily oral low dose of Cl:ZnO (5 mg/kg b.w), G6: treated with STZ (60 $\mathrm{mg} / \mathrm{kg} \mathrm{b.w})+$ single daily oral high dose of Cl:ZnO $(10 \mathrm{mg} / \mathrm{kg}$ b.w). Rats were sacrificed at $0,24,48$, and $72 \mathrm{~h}$ after STZ treatment. Before the rats were sacrificed, blood was collected from the orbital sinus and serum was prepared and kept frozen at $-20^{\circ} \mathrm{C}$ until the time of assay. The rats were killed by decapitation and the livers were rapidly excised, rinsed in saline, blotted, and weighed. Each eye was immediately enucleated, the lens was removed, and the retina was gently peeled away from the pigment epithelium and placed in 500 1'l $^{\prime} \mathrm{ice}$-chilled $10 \mathrm{mmol} / \mathrm{l}$ sodium phosphate buffer, $\mathrm{pH} 8.0$.

\section{Measurements of blood glucose and insulin}

Blood glucose $(\mathrm{mg} / \mathrm{dL})$ was estimated by glucose oxidase method using the kitsupplied by SPINREACT (SantEstevadeBas, Girona, Spain) according to Tietz, [26], we measured blood glucose in all experimental animals before the beginning ofthe experimental procedures, after streptozotocin injection. After that, blood glucose was monitored in all experimental animals, and results were obtained at $0,24,48$ and $72 \mathrm{~h}$ of the experimental period. Serum insulin was measured using an insulin radio immunoassay kit.

\section{Measurements of sAST and sALT}

Serum transaminases sAST and sALT (Aspartate transferase and Alanine transferase) were measured colorimetrically according to the method described Reitaman and Frankel [27].

\section{Assessment of lipid peroxidation}

Retinal and liver homogenates $(10 \% \mathrm{w} / \mathrm{v}$ in cold distilled water) were used for the estimation of the degree of lipid peroxidation. The level of lipid peroxidation was estimated by the thiobarbituric acid (TBA) test according to the method described by Uchiyama and Mihara, [28]. Briefly, an aliquot $(0.5 \mathrm{ml})$ of the retinal or liver homogenate was mixed with $1.0 \%$ phosphoric acid $(3 \mathrm{ml}, \mathrm{pH} 2.0)$ and $0.6 \%$ TBA (1 $\mathrm{ml}$ ) in airtight tubes and kept in a boiling water bath for $45 \mathrm{~min}$. The samples were cooled in ice and butanol $(5 \mathrm{ml})$ was added along with through mixing of the mixture. The butanol phase was separated by centrifugation $(1000 \times \mathrm{g})$ and transferred to glass cuvettes. The color of the TBA chromogen was measured at 520 and $532 \mathrm{~nm}$ using a spectrophotometer (Bauch and Lomb, Spectronic-20). The difference between absorbance at 520 and at $532 \mathrm{~nm}$ gave the TBA value, which primarily represents the malondialdehyde concentration and was taken as the measure of lipid peroxidation $[29,30]$.

\section{Measurements of reduced glutathione (GSH)}

Reduced glutathione was measured according to the method of Sedlak and Lindsay, [31]. A $400 \mathrm{mg}$ sample of retina was homogenized in $8.0 \mathrm{ml}$ of 0.02 M EDTA using an all-glass Ten-Broeck homogenizer in an ice bath. These ratios of tissue to homogenizing medium were chosen to obtain an absorbance of 0.1 to 0.8 when $5.0 \mathrm{ml}$ was used for the estimation of GSH. Aliquots of $5 \mathrm{ml}$ of homogenates were mixed with $4.0 \mathrm{ml}$ of distilled water and $1.0 \mathrm{ml}$ of $50 \%$ trichloroacetic acid (TCA). The tubes were shaken intermittently for 10-15 min and centrifuged for $15 \mathrm{~min}$ at approximately $3000 \times \mathrm{g}$. Two $\mathrm{ml}$ of supernatant was mixed with $4.0 \mathrm{ml}$ Tris buffer, $\mathrm{pH}$ 8.9, $0.1 \mathrm{ml}$ of DTNB was then added and the sample was shaken. The absorbance was read within 5 min of the addition of DTNB at $412 \mathrm{Am}$ against a reagent blank with no homogenate.

\section{Statistical analysis}

The results are represented as mean \pm SE and statistically analyzed by using one-way ANOVA. Accepted level of significance $(\mathrm{P} \leq 0.05)$.

\section{Results and Discussion}

\section{Characterization}

IR spectra: Figure 1 shows the FT-IR absorption spectrum of F: $\mathrm{ZnO}$ and $\mathrm{Cl}: \mathrm{ZnO}$ nanoparticles. The peak at $470 \mathrm{~cm}^{-1}$ is the characteristic distinct stretching vibration of zinc oxide. The broad absorption peak at $3400 \mathrm{~cm}^{-1}$ can be attributed to the characteristic absorption of hydroxyls group.

Scan electron microscope: Figure 2 shows the SEM images of the $\mathrm{ZnO}$ nano powders prepared with fluorine and chlorine doping. As can see from Figure 2a, the F:ZnO nanoparticles shows rode shape. But in case of $\mathrm{Cl}: \mathrm{ZnO}$ the $\mathrm{ZnO}$ shows a round shape. The difference in the shape can be attributed to the nature of doping

Transmission electron microscope: Figure 3 shows that the $\mathrm{ZnO}$ nano powders prepared with fluorine and chlorine doping have average particle size 17.7 and $59.3 \mathrm{~nm}$, respectively. 
Citation: El-Rahman SNA, Reda SM, AIGhannam SM (2016) Synthesis and Characterization of Nano-doped Zinc Oxide and its Application as Protective Oxidative Changes in the Retina of Diabetic Rats. J Diabetes Metab 7: 691. doi: 10.4172/2155-6156.1000691

Page 3 of 6

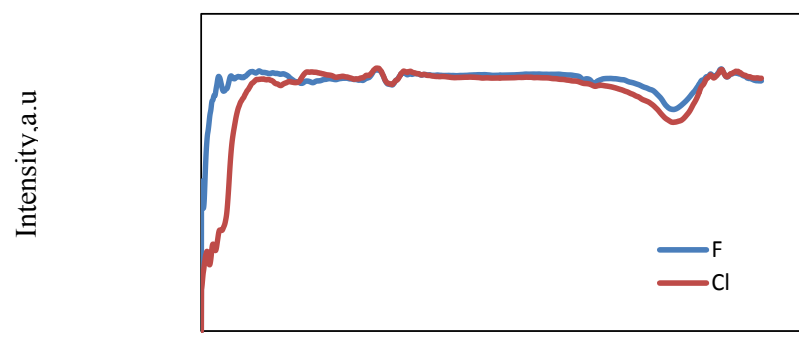

Wavenumber, $\mathrm{cm}^{-1}$

Figure 1: FTIR spectra of $\mathrm{F}$ : and $\mathrm{Cl}: \mathrm{ZnO}$ powder.

(a)

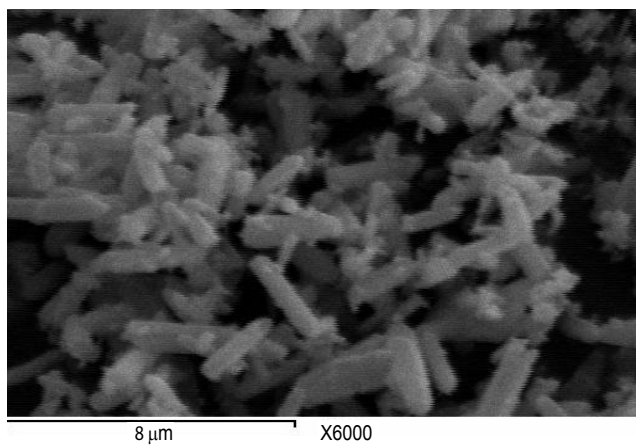

(b)

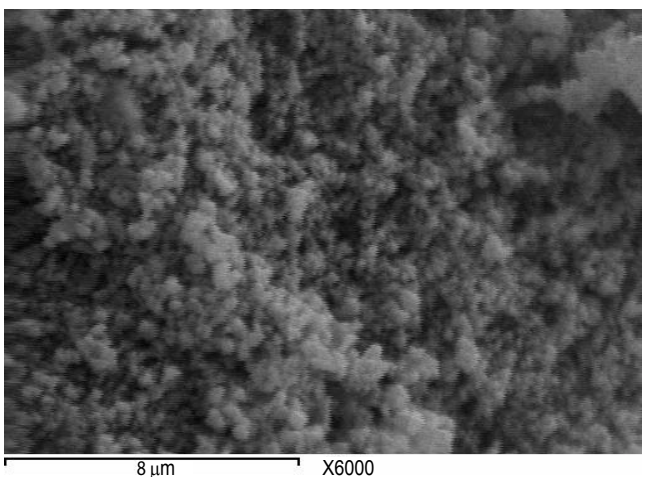

Figure 2: SEM spectra of $\mathrm{F}$ : (a) and $\mathrm{Cl}: \mathrm{ZnO}$ powder (b).

BET measurement: The values of surface area of the $\mathrm{F}: \mathrm{ZnO}$ and $\mathrm{Cl}: \mathrm{ZnO}$ nano particles were found to be 3.55 and $41.62 \mathrm{~m}^{2} / \mathrm{g}$, respectively. The high value of surface area of chlorine composite facilitates adsorption on its surface.

X-ray: XRD patterns of the $\mathrm{ZnO}$ nanocomposites are shown in Figure 4 . The diffraction peaks from the $\mathrm{ZnO}$ at $2 \theta=\left(31.9^{\circ}\right),\left(34.6^{\circ}\right)$, $\left(36.4^{\circ}\right),\left(47.7^{\circ}\right),\left(56.7^{\circ}\right),\left(62.9^{\circ}\right)$, and $\left(68.1^{\circ}\right)$ to the $\left(\begin{array}{lll}1 & 0 & 0\end{array}\right),\left(\begin{array}{lll}0 & 0 & 2\end{array}\right),(1$ $\left.\begin{array}{ll}0 & 1\end{array}\right),(102),\left(\begin{array}{ll}103\end{array}\right),\left(\begin{array}{lll}1 & 1 & 2\end{array}\right)$ and $\left(\begin{array}{lll}2 & 0 & 1\end{array}\right)$ diffraction planes, respectively. These diffraction planes can be indexed to the Zinc its structure of $\mathrm{ZnO}$ indicating its high crystallinity [32].

Biological study: Diabetic retinopathy is likely to be multifactorial. Recognition of as many of these factors as possible and study of their interaction may help overcome the vision impairment or blindness that accompany diabetes. Oxidative stress has been found to play an important role in the pathogenesis of diabetes [33-35]. Also, the generation of reactive oxygen species has been shown to play an integral and possibly a causative part in the pathogenesis of diabetic retinopathy [35-37]. Previous studies investigated that ZnONPs have diabetic protection properties, but there is no previous study carried out with $\mathrm{F}: \mathrm{ZnO}, \mathrm{Cl}-\mathrm{ZnO}$ and diabetic retinopathy. So, our study conducted to evaluate $\mathrm{F}: \mathrm{ZnO}$ and $\mathrm{Cl}-\mathrm{ZnO}$ effects on diabetic retinopathy protection. Also, the demonstrated results might be a base for further studies with $\mathrm{F}: \mathrm{ZnO}$ and $\mathrm{Cl}-\mathrm{ZnO}$.

Table 1 shows the levels of serum glucose concentrations in diabetic rats administration low and high dose of $\mathrm{F}: \mathrm{ZnO}$ and $\mathrm{Cl}: \mathrm{ZnO}$ for 3 days. Our results showed a great reduction in blood glucose level in diabetic groups treated with low and high dose of F:ZnOandCl: $\mathrm{ZnO}$, it found to be $119.03,117.10,108.97$ and $103.97 \mathrm{mg} / \mathrm{dl}$ after $72 \mathrm{~h}$, respectively. This showed a great antidiabetic activity of zinc oxide nanoparticles, as zinc has been elucidated to be a potent metal that improves glucose utilization and metabolism through its potent influence on
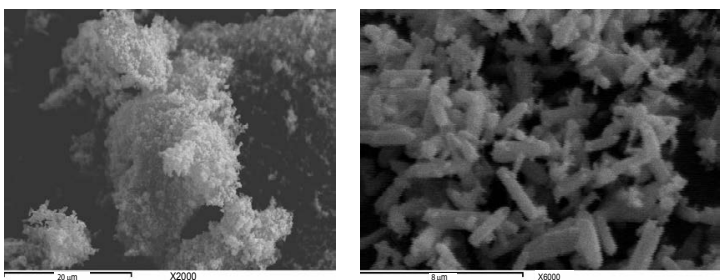

Figure 3: TEM spectra of $\mathrm{F}:(\mathrm{b})$ and $\mathrm{Cl}$ : ZnO powder (a).

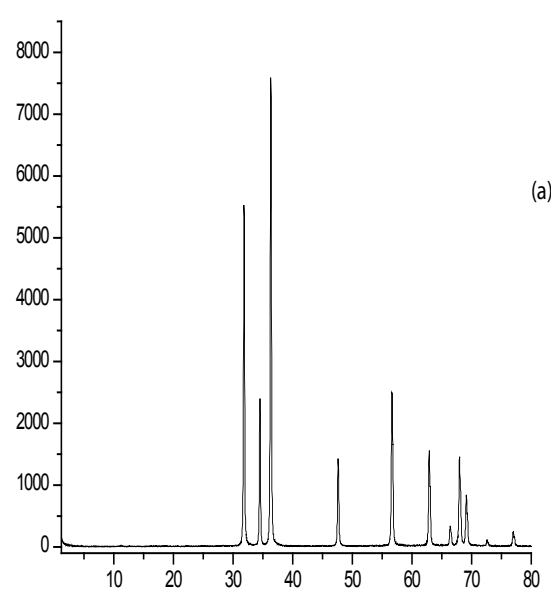

$\mathrm{F}$

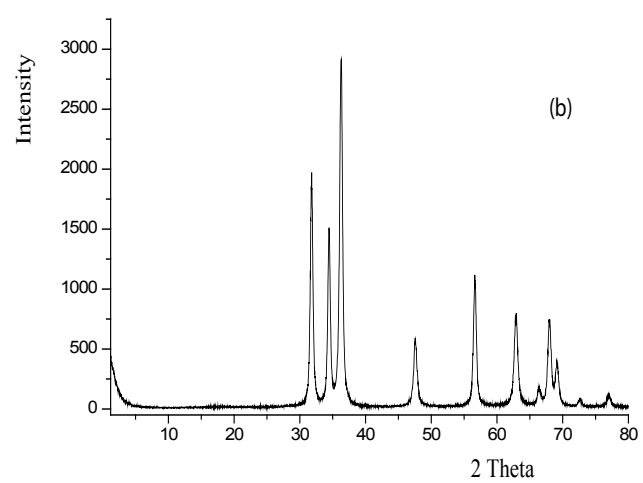

Figure 4: X-ray of $\mathrm{ZnO}$ nano composites. 
Citation: El-Rahman SNA, Reda SM, AIGhannam SM (2016) Synthesis and Characterization of Nano-doped Zinc Oxide and its Application as Protective Oxidative Changes in the Retina of Diabetic Rats. J Diabetes Metab 7: 691. doi: 10.4172/2155-6156.1000691

enhancement of hepatic glycogenesis through actions on the insulin signaling pathway [38]. These results agree with the results reported by Umrani, and Paknikar, [25] they indicated that repeated administration of $\mathrm{ZnONPs}$ to diabetic rats showed better effects on glucose intolerance compared with single-dose studies, suggesting improved efficacy after multiple dosing. Single administration of ZnONPs resulted in prominent glucose suppression during oral glucose tolerance test (OGGT), suggesting antidiabetic effects. Improved glucose tolerance in OGTT could be as a result of several possible mechanisms. I. ZnONPs treatment might result in inhibition of intestinal a-glucosidase enzyme and thereby reduce glucose absorption. II. glucose uptake increased in the liver and its subsequent storage (glycogenesis) might be lowered blood glucose levels. III. Enhanced glycolysis by ZnONPs could result in improved glucose disposal. Also, the antidiabetic effects of ZnONPs may be due to that zinc is closely involved in general metabolism of protein, carbohydrate, and lipids. In the case of glucose metabolism, zinc is a cofactor of key enzymes. It is an activator of fructose 1-6 diphosphatealdolase, and an inhibitor of fructose 1-6 diphosphatase [39]. ZnONPs treatment indicates inhibitory effects on glycogenolysis and gluconeogenesis, mechanisms that are active during the fasted state. Additionally, Egefjord et al. [40] investigated that zinc regulate glucagon secretion from pancreatic acells. As a result, glucagonstimulated hepatic pathways (i.e., glycogenesis and gluconeogenesis) would be suppressed in the fasting state [41] contributing to a reduction of fasted glucose levels.

Serum insulin levels in diabetic rats administration low and high dose of $\mathrm{F}: \mathrm{ZnO}$ and $\mathrm{Cl}: \mathrm{ZnO}$ for 3 days were presented in Table 2. The results show that the groups administration high dose of $\mathrm{F}: \mathrm{ZnO}$ and $\mathrm{Cl}: \mathrm{ZnO}$ gave a best results $(326.40$ and $367.80 \mathrm{pg} / \mathrm{ml})$, respectively, compared to PC $(175.40 \mathrm{pg} / \mathrm{ml})$. There are few studies that have investigated the therapeutic effect of $\mathrm{ZnONPs}$ on insulin levels or secretion. zinc could enhance the glucose stimulated insulin secretion from rat isolated pancreatic islets [42]. Umrani and Paknikar [25] demonstrated that $\mathrm{ZnONPs}$ did not possess the risk of hypoglycemia in living organisms so it can act as an insulin secretor. Additionally, increase serum insulin level in diabetic groups administration of ZnONPs may be due to accumulation of zinc in the secretory vesicle of B cells using transporter 8 [43]. Zinc transporters are also identified in adipose tissues and liver [44]. Quarterman et al. [45] reported that diet induced zinc deficiency in rats resulted in a decrease in the ability of the pancreas to secrete insulin in response to a glucose load. Meyer and Spence [46] indicated that decreased zinc in the pancreas may reduce the ability of the islet b-cells to produce and secrete insulin and zinc deficiency is positively correlated with diabetes and may also affect the progress of Type 2 diabetes [47].

Our results pointed out that there is a significant increase in the levels of concentration of TBA (MDA) in liver and retinal and GSH in retinal of diabetic rats (Tables 3 and 4), in contrast, was significantly reduced after treatment by low and high dose of $\mathrm{F}: \mathrm{ZnO}$ and $\mathrm{Cl}: \mathrm{ZnO}$ for 3 days. Zinc is a necessary factor in the variety of antioxidant enzymes e.g. Zn superoxide dismutase, $\mathrm{Zn}$-metallothionein etc. [32]. Also, Znmetallothionein complex in the islets cells provides protection against free radicals produced in the cell from any cause. The more depleted the intracellular $\mathrm{Zn}$ stores, the less able the cell is to defend itself against this oxidative load. Aruoma [48] concluded that Copper and zinc, and manganese are indispensable metals for the activities of $\mathrm{Cu}, \mathrm{Zn}$-SOD and $\mathrm{Mn}$-SOD, respectively. Therefore, dietary deficiencies of these minerals markedly decrease tissue $\mathrm{Cu}, \mathrm{Zn}$-SOD and Mn-SOD activities and result in peroxidative damage and mitochondrial dysfunction.

\begin{tabular}{|c|c|c|c|c|}
\hline \multirow{2}{*}{\begin{tabular}{|lr} 
Treatments & Time \\
\end{tabular}} & \multicolumn{4}{|c|}{ Glucose (mg/dl) } \\
\hline & Oh & $24 \mathrm{~h}$ & $48 \mathrm{~h}$ & $72 \mathrm{~h}$ \\
\hline $\mathrm{G} 1(\mathrm{NC})$ & $95.09^{b} \pm 0.079$ & $95.818^{d} \pm 0.122$ & $94.582^{f} \pm 0.170$ & $95.942^{f} \pm 0.100$ \\
\hline $\mathrm{G} 2(\mathrm{PC})$ & $94.996^{b} \pm 0.063$ & $155.402^{\mathrm{a}} \pm 0.616$ & $204.288^{a} \pm 0.525$ & $380.534^{a} \pm 0.475$ \\
\hline G3 & $95.566^{a} \pm 0.125$ & $102.612^{\mathrm{b}} \pm 0.176$ & $112.114^{b} \pm 0.273$ & $119.032^{b} \pm 0.155$ \\
\hline G4 & $94.17^{\mathrm{c}} \pm 0.258$ & $102.612^{b} \pm 0.176$ & $110.194^{\mathrm{c}} \pm 0.288$ & $117.104^{c} \pm 0.273$ \\
\hline G5 & $95.188^{a b} \pm 0.172$ & $98.05^{\circ} \pm 0.049$ & $102.114^{d} \pm 0.273$ & $108.972^{d} \pm 0.046$ \\
\hline G6 & $95.012^{b} \pm 0.016$ & $96.39^{d} \pm 0.193$ & $98.664^{e} \pm 0.209$ & $103.974^{\mathrm{e}} \pm 0.040$ \\
\hline LSD & 0.417 & 0.840 & 0.908 & 0.693 \\
\hline
\end{tabular}

NC $=$ Negative controlPC $=$ positive control (treated with STZ 60mg $/ \mathrm{kg} \mathrm{B.W}$ )

G3 = Treated withSTZ + F:ZnO (low dose)G4= treated with STZ +F:ZnO (high dose)

$\mathbf{G 5}=$ treated with $\mathrm{STZ}+\mathrm{Cl}: \mathrm{ZnO}($ low dose) G6= treated with $\mathrm{STZ}+\mathrm{Cl}: \mathrm{ZnO}$ (high dose)

Statistically significant at $\mathrm{P}<0.05$ as compared to NC (one-way ANOVA followed by Fischer's LSD test)

Table 1: Effect of $\mathrm{F}: \mathrm{ZnO}$ and $\mathrm{Cl}: \mathrm{ZnO}(5 \mathrm{mg} / \mathrm{kg}$ b.w and $10 \mathrm{mg} / \mathrm{kg} \mathrm{b} . \mathrm{w})$ on serum glucose concentration in diabetic rats.

\begin{tabular}{|c|c|c|c|c|}
\hline \multirow[b]{2}{*}{ Treatments } & \multicolumn{4}{|c|}{ Insulin (pg/ml) } \\
\hline & Oh & $24 \mathrm{~h}$ & $48 h$ & $72 \mathrm{~h}$ \\
\hline G1 (NC) & $469.40^{\mathrm{bc}} \pm 0.93$ & $474.00^{\mathrm{a}} \pm 1.10$ & $473.40^{\mathrm{a}} \pm 1.47$ & $478.60^{\mathrm{a}} \pm 2.73$ \\
\hline $\mathrm{G} 2(\mathrm{PC})$ & $476.60^{\mathrm{a}} \pm 1.03$ & $334.80^{\mathrm{e}} \pm 0.58$ & $203.60^{f} \pm 0.60$ & $175.40^{f} \pm 0.93$ \\
\hline G3 & $467.20^{c} \pm 0.73$ & $352.00^{d} \pm 0.32$ & $301.80^{e} \pm 0.37$ & $288.40^{e} \pm 0.24$ \\
\hline G4 & $472.00^{\mathrm{b}} \pm 1.00$ & $392.00^{c} \pm 0.32$ & $365.00^{\circ} \pm 1.30$ & $326.40^{c} \pm 0.24$ \\
\hline G5 & $475.00^{\mathrm{a}} \pm 0.95$ & $392.40^{c} \pm 0.24$ & $341.40^{d} \pm 0.40$ & $308.40^{d} \pm 0.24$ \\
\hline G6 & $469.60^{\mathrm{bc}} \pm 1.29$ & $413.20^{b} \pm 0.80$ & $387.00^{b} \pm 4.53$ & $367.80^{\mathrm{b}} \pm 1.07$ \\
\hline LSD & 2.924 & 1.861 & 5.960 & 3.700 \\
\hline
\end{tabular}

NC $=$ Negative controlPC $=$ positive control (treated with STZ 60mg $/ \mathrm{kg} \mathrm{B.W}$ )

G3 = Treated withSTZ $+F: Z n O$ (low dose) $G 4=$ treated with $S T Z+F: Z n O$ (high dose)

G5 = Treated with STZ $+\mathrm{Cl}: \mathrm{ZnO}($ low dose) $\mathrm{G} 6=$ treated with $\mathrm{STZ}+\mathrm{Cl}: \mathrm{ZnO}$ (high dose)

Statistically significant at $\mathrm{P}<0.05$ as compared to NC (one-way ANOVA followed by Fischer's LSD test)

Table 2: Effect of $\mathrm{F}: \mathrm{ZnO}$ and $\mathrm{Cl}: \mathrm{ZnO}(5 \mathrm{mg} / \mathrm{kg}$ b.w and $10 \mathrm{mg} / \mathrm{kg}$ b.w) on serum Insulin concentration in diabetic rats. 
Citation: El-Rahman SNA, Reda SM, AIGhannam SM (2016) Synthesis and Characterization of Nano-doped Zinc Oxide and its Application as Protective Oxidative Changes in the Retina of Diabetic Rats. J Diabetes Metab 7: 691. doi: 10.4172/2155-6156.1000691

Page 5 of 6

\begin{tabular}{|c|c|c|c|c|c|c|c|c|}
\hline \multirow{2}{*}{ Treatments } & \multicolumn{4}{|c|}{ TBA $(\mu \mathrm{M})$ liver } & \multicolumn{4}{|c|}{ TBA $(\mu M)$ Retinal } \\
\hline & Oh & $24 \mathrm{~h}$ & $48 h$ & $72 \mathrm{~h}$ & Oh & $24 \mathrm{~h}$ & $48 h$ & $72 \mathrm{~h}$ \\
\hline G1 (NC) & $8.716^{a} \pm 0.113$ & $8.692^{\mathrm{e}} \pm 0.091$ & $8.506^{e} \pm 0.085$ & $8.55^{\mathrm{e}} \pm 0.133$ & $6.282^{\mathrm{a}} \pm 0.014$ & $6.202^{b} \pm 0.018$ & $6.222^{\mathrm{e}} \pm 0.024$ & $6.238^{\mathrm{e}} \pm 0.032$ \\
\hline G2 (PC) & $8.756^{a} \pm 0.077$ & $17.032^{\mathrm{a}} \pm 0.048$ & $19.974^{\mathrm{a}} \pm 0.054$ & $21^{a} \pm 0.031$ & $6.256^{a} \pm 0.029$ & $14.9402^{\mathrm{a}} \pm 1.993$ & $18.062^{\mathrm{a}} \pm 0.020$ & $18.558^{a} \pm 0.034$ \\
\hline G3 & $8.586^{a} \pm 0.044$ & $10.172^{b} \pm 0.011$ & $10.246^{b} \pm 0.037$ & $10.654^{b} \pm 0.074$ & $6.25^{\mathrm{a}} \pm 0.019$ & $7.062^{b} \pm 0.016$ & $7.132^{b} \pm 0.012$ & $7.498^{b} \pm 0.029$ \\
\hline G4 & $8.584^{a} \pm 0.082$ & $9.892^{c} \pm 0.057$ & $9.506^{c} \pm 0.085$ & $9.514^{c} \pm 0.090$ & $6.256^{a} \pm 0.029$ & $6.942^{\mathrm{b}} \pm 0.044$ & $6.962^{c} \pm 0.032$ & $7.06^{c} \pm 0.028$ \\
\hline G5 & $8.714^{a} \pm 0.098$ & $8.952^{d} \pm 0.019$ & $8.996^{d} \pm 0.024$ & $9.07^{d} \pm 0.032$ & $6.036 \pm 0.011$ & $6.32^{b} \pm 0.023$ & $6.382^{d} \pm 0.047$ & $6.52^{\mathrm{d}} \pm 0.023$ \\
\hline G6 & $8.292^{\mathrm{b}} \pm 0.082$ & $8.892^{d} \pm 0.030$ & $8.886^{d} \pm 0.029$ & $8.52^{\mathrm{e}} \pm 0.138$ & $6.224^{a} \pm 0.032$ & $6.19^{b} \pm 0.025$ & $6.134^{f} \pm 0.020$ & $6.146^{f} \pm 0.009$ \\
\hline LSD & 0.249 & 0.147 & 0.169 & 0.272 & 0.069 & 2.376 & 0.082 & 0.080 \\
\hline
\end{tabular}

NC $=$ Negative controlPC $=$ positive control (treated with STZ 60mg $/ \mathrm{kg} \mathrm{B.W}$ )

G3 = Treated withSTZ $+F: Z n O$ (low dose) $\mathrm{G} 4=$ treated with $\mathrm{STZ}+\mathrm{F}: \mathrm{ZnO}$ (high dose)

$\mathrm{G} 5=$ Treated with $\mathrm{STZ}+\mathrm{Cl}: \mathrm{ZnO}$ (low dose) $\mathrm{G} 6=$ treated with $\mathrm{STZ}+\mathrm{Cl}: \mathrm{ZnO}$ (high dose)

Statistically significant at $\mathrm{P}<0.05$ as compared to NC (one-way ANOVA followed by Fischer's LSD test)

Table 3: Effect of $\mathrm{F}: \mathrm{ZnO}$ and $\mathrm{Cl}: \mathrm{ZnO}(5 \mathrm{mg} / \mathrm{kg}$ b.w and $10 \mathrm{mg} / \mathrm{kg} \mathrm{b.w})$ on liver and retinal TBAconcentration.

\begin{tabular}{|c|c|c|c|c|}
\hline \multirow[b]{2}{*}{ Treatments } & \multicolumn{4}{|c|}{ GST (nmol/min/ml) } \\
\hline & $\mathbf{O h}$ & $24 \mathrm{~h}$ & $48 \mathrm{~h}$ & $72 \mathrm{~h}$ \\
\hline $\mathrm{G} 1(\mathrm{NC})$ & $27.578^{a} \pm 0.156$ & $27.49^{f} \pm 0.086$ & $27.566^{d} \pm 0.075$ & $27.742^{\mathrm{d}} \pm 0.087$ \\
\hline G2 (PC) & $27.678^{a} \pm 0.063$ & $37.694^{a} \pm 0.061$ & $47.514^{a} \pm 0.081$ & $49.862^{\mathrm{a}} \pm 0.097$ \\
\hline G3 & $27.68^{a} \pm 0.080$ & $30.158^{b} \pm 0.051$ & $30.556^{b} \pm 0.048$ & $29.196^{b} \pm 0.153$ \\
\hline G4 & $27.784^{a} \pm 0.092$ & $29.168^{c} \pm 0.067$ & $29.276^{c} \pm 0.069$ & $28.236^{c} \pm 0.048$ \\
\hline G5 & $26.854^{b} \pm 0.051$ & $28.432^{\mathrm{d}} \pm 0.232$ & $27.476^{d} \pm 0.159$ & $27.436^{d} \pm 0.161$ \\
\hline G6 & $26.96^{b} \pm 0.053$ & $27.888^{e} \pm 0.099$ & $27.436^{d} \pm 0.116$ & $27.566^{d} \pm 0.138$ \\
\hline LSD & 0.263 & 0.341 & 0.287 & 0.352 \\
\hline
\end{tabular}

NC $=$ Negative controlPC $=$ positive control (treated with STZ $60 \mathrm{mg} / \mathrm{kg} \mathrm{B.W}$ )

G3= Treated withSTZ +F:ZnO (low dose) G4= treated with STZ +F:ZnO (high dose)

G5 = Treated with STZ $+\mathrm{Cl}: \mathrm{ZnO}$ (low dose) G6= treated with $\mathrm{STZ}+\mathrm{Cl}: \mathrm{ZnO}$ (high dose)

Statistically significant at $\mathrm{P}<0.05$ as compared to NC (one-way ANOVA followed by Fischer's LSD test)

Table 4: Effect of $\mathrm{F}: \mathrm{ZnO}$ and $\mathrm{Cl}: \mathrm{ZnO}(5 \mathrm{mg} / \mathrm{kg}$ b.w and $10 \mathrm{mg} / \mathrm{kg}$ b.w) on liver GSHconcentration in diabetic rats.

\begin{tabular}{|c|c|c|}
\hline Treatments & ALT (U/ L) & AST(U/ L) \\
\hline G1 (NC) & $37.12^{\mathrm{f}} \pm 0.085$ & $25.02^{\mathrm{d}} \pm 0.124$ \\
\hline G2 (PC) & $65.692^{\mathrm{a}} \pm 0.202$ & $44.304^{\mathrm{a}} \pm 0.338$ \\
\hline G3 & $45.096^{\mathrm{b}} \pm 0.069$ & $28.2^{\mathrm{b}} \pm 0.090$ \\
\hline G4 & $42.214^{\mathrm{c}} \pm 0.050$ & $27.06^{\mathrm{c}} \pm 0.043$ \\
\hline G5 & $38.062^{\mathrm{d}} \pm 0.024$ & $27.02^{\mathrm{c}} \pm 0.019$ \\
\hline G6 & $37.568^{\mathrm{e}} \pm 0.038$ & $25.3^{\mathrm{d}} \pm 0.175$ \\
\hline
\end{tabular}

NC $=$ Negative controlPC $=$ positive control (treated with STZ 60mg $/ \mathrm{kg} \mathrm{B.W}$ )

G3 = Treated withSTZ +F:ZnO (low dose)G4= treated with STZ +F:ZnO (high dose)

G5 = Treated with $\mathrm{STZ}+\mathrm{Cl}: \mathrm{ZnO}($ low dose)G6= treated with $\mathrm{STZ}+\mathrm{Cl}: \mathrm{ZnO}$ (high dose)

Statistically significant at $\mathrm{P}<0.05$ as compared to NC (One-way ANOVA followed by Fischer's LSD test)

Table 5: Effect of $\mathrm{F}: \mathrm{ZnO}$ and $\mathrm{Cl}: \mathrm{ZnO}(5 \mathrm{mg} / \mathrm{kg}$ b.w and $10 \mathrm{mg} / \mathrm{kg}$ b.w) on serum ALT and AST concentrations in diabetic rats.

The results presented in Table 5 show the levels of sALT and sAST in diabetic rats administration low and high dose of F:ZnO and $\mathrm{Cl}: Z n O f o r ~ 3$ days. It was observed that there was serum sALT and sAST significantly $(\mathrm{P} \leq 0.05)$ increased $(65.692$ and $44.304 \mathrm{mg} / \mathrm{dl})$ in $\mathrm{PC}$ compared to $\mathrm{NC}(37.12$ and $25.02 \mathrm{mg} / \mathrm{dl})$, respectively. On the other hand, the group treated with high dose of $\mathrm{Cl}: \mathrm{ZnO}$ gave the best results compared to other groups. The present findings are in agreement with those obtained by SubashBabu et al. [49] whom said that the activities of plasma enzymes AST, ALT, LDH, ALP and ACP significantly $(p<0.05)$ increased in diabetic rats compared to controls.

\section{Conclusion}

$\mathrm{Cl}: \mathrm{ZnO}$ and F:ZnO were elucidated as antidiabetic agents. They lead to induction of insulin synthesis and decreasing of blood glucose also has a depressant effects of lipids oxidation. The current results clearly investigate the beneficial effects of high dose of $\mathrm{F}: \mathrm{ZnO}$ and
$\mathrm{Cl}: \mathrm{ZnO}$ in both controlling hyperglycemia and the protection of the retina against oxidative stress, but $\mathrm{Cl}: \mathrm{ZnO}$ gave the best results. From the above results we can say that the best performance of $\mathrm{Cl}: \mathrm{ZnO}$ is due to its high value of surface area compared to F: $\mathrm{ZnO}$.

\section{Acknowledgement}

This paper contains the results and findings of a research project funded by King Abdulaziz City for Science and Technology (KACST) Grant No A-T-32-38 The authors are grateful for the assistance of the Field Crop Technology Research Department, Food Technology Research Institute, Agricultural Research Center, Giza, Egypt. We gratefully acknowledge the assistance of the animal house of Ophthalmology Research Institute, Giza, Egypt.

\section{References}

1. Lin Y, Sun $Z$ (2010) Current views on type 2 diabetes. J Endocrinol 204: 1-11.

2. Pfeiffer A, Schatz H (1995) Diabetic microvascular complications and growth factors. Exp Clin Endocrinol Diabetes 103: 7-14. 
Citation: El-Rahman SNA, Reda SM, AIGhannam SM (2016) Synthesis and Characterization of Nano-doped Zinc Oxide and its Application as Protective Oxidative Changes in the Retina of Diabetic Rats. J Diabetes Metab 7: 691. doi: 10.4172/2155-6156.1000691

3. Frank RN (1991) On the pathogenesis of diabetic retinopathy. A 1990 update Ophthalmology 98: 586-593.

4. Agardh CD, Stenram U, Torffvit O, Agardh E (2002) Effects of inhibition of glycation and oxidative stress on the development of diabetic nephropathy in rats. J Diabetes Complications 16: 395-400.

5. Endo M, Yanagisawa K, Tsuchida K, Okamoto T, Matsushita T, et al. (2001) Increased levels of vascular endothelial growth factor and advanced glycation end products in aqueous humor of patients with diabetic retinopathy. Horm Metab Res 33: 317-320.

6. Kalousova M, Skrha J, Zima T (2002) Advanced glycation end-products and advanced oxidation protein products in patients with diabetes mellitus. Physiol Res 51: 597-604.

7. Wautier JL, Guillausseau PJ (2001) Advanced glycation end products, their receptors and diabetic angiopathy. Diabetes Metab 27: 535-542.

8. Brownlee M, Vlassara H, Cerami A (1984) Nonenzymatic glycosylation and the pathogenesis of diabetic complications. Ann Intern Med 101: 527-537.

9. Agardh E, Hultberg B, Agardh C (2000) Effects of inhibition of glycation and oxidative stress on the development of cataract and retinal vessel abnormalities in diabetic rats. Curr Eye Res 21: 543-549.

10. Ansari NH, Zhang W, Fulep E, Mansour A (1998) Prevention of pericyte loss by trolox in diabetic rat retina. J Toxicol Environ Health A 54: 467-475.

11. Kowluru RA, Kennedy A (2001) Therapeutic potential of anti-oxidants and diabetic retinopathy. Expert Opin Investig Drugs 10: 1665-1676.

12. Kowluru RA, Tang J, Kern TS (2001) Abnormalities of retinal metabolism in diabetes and experimental galactosemia. VII. Effect of long-term administration of antioxidants on the development of retinopathy. Diabetes 50: 1938-1942.

13. Maejima K, Nakano S, Himeno M, Tsuda S, Makiishi H, et al. (2001) Increased basal levels of plasma nitric oxide in Type 2 diabetic subjects. Relationship to microvascular complications. J Diabetes Its Complicat 15: 135-143.

14. Obrosova IG, Minchenko AG, Marinescu V, Fathallah L, Kennedy A, et al. (2001) Antioxidants attenuate early up regulation of retinal vascular endothelial growth factor in streptozotocin-diabetic rats. Diabetologia 44: 1102-1110.

15. Wang ZL (2004) Mater Today 7: 26-33.

16. Tian ZR, Voigt JA, Liu J, McKenzie B, McDermott MJ, et al. (2003) Complex and oriented $\mathrm{ZnO}$ nanostructures. Nat Mater 2: 821-826.

17. Yang Z, Liu QH (2008) Physica 40: 531-536

18. Zhu X, Yuri I, Gan X, Suzuki I, Li G (2007) Electrochemical study of the effect of nano-zinc oxide on microperoxidase and its application to more sensitive hydrogen peroxide biosensor preparation. Biosens Bioelectron 22: 1600-1604.

19. Rudolf E, Peychl J, Radocha J, Cervinka M (2001) Zinc and its role in the regulation of cell death. Cesk Fysiol 50: 201-210.

20. Hanna PM, Kaiiska MB, Jordan SJ, Mason RP (1993) Role ofmetallothionine in zinc (II) and Chromium (III) mediated tolerance to carbon tetrachloride hepatotoxicity: evidence against a trichloromethyl radical-scavenging mechanism. Chem Res Toxicol 6: 711-717.

21. Moustafa SA (2001) Effect of glutathione (GSH) depletion on the serum levels of triiodothyronine (T3), thyroxine (T4), and T3/T4 ratio in allyl alcohol-treated male rats and possible protection with zinc. Int J Toxicol 20: 15-20.

22. Moustafa SA, Nabil Zl, Ahmed SH (2000) Protective effects of zinc agains cadmium chloride cytotoxicity in the rat. Res Commun Pharmacol Toxicol 5 : 205-220.

23. Provinciali M, Donnini A, Argentati K, Di Stasio G, Bartozzi B, et al. (2002) Reactive oxygen species modulate $\mathrm{Zn}(2+)$-induced apoptosis in cancer cells. Free Radic Biol Med 32: 431-445.

24. Alkaladi A, Abdelazim AM, Afifi M (2014) Antidiabetic activity of zinc oxide and silver nanoparticles on streptozotocin-induced diabetic rats. Int J Mol Sci 15 : 2015-2023.

25. Umrani RD, Paknikar KM (2014) Zinc oxide nanoparticles show antidiabetic activity in streptozotocin-induced Type 1 and 2 diabetic rats. Nanomedicine (Lond) 9: 89-104.

26. Tietz NW (1995) Clinical guide to laboratory tests. 3rd edn. Philadelphia: WB saunders pp: $268-273$.
27. Reitaman S, Frankel S (1957) A colorimetric method for the determination of serum glutamic oxaloacetic and glutamic pyruvic transaminases. American Journal of Clinical Pathology 28: 56.

28. Mihara M, Uchiyama M (1978) Determination of malonaldehyde precursor in tissues by thiobarbituric acid test. Anal Biochem 86: 271-278.

29. Yonaha M, Itoh E, Ohbayashi Y, Uchiyama M (1980) Induction of lipid peroxidation in rats by mercuric chloride. Res Commun Chem Pathol Pharmacol 28: 105-112.

30. Sohal RS, Donato H, Biehl ER (1981) Effect of age and metabolic rate on lipid peroxidation in the housefly, Musca domestica L. Mech Ageing Dev 16: 159167.

31. Sedlak J, Lindsay RH (1968) Estimation of total, protein-bound, and nonprotein sulfhydryl groups in tissue with Ellman's reagent. Anal Biochem 25: 192-205.

32. Chausmer AB (1998) Zinc, insulin and diabetes. J Am Coll Nutr 17: 109-115.

33. Hiramatsu K, Arimori S (1988) Increased superoxide production by mononuclear cells of patients with hypertriglyceridemia and diabetes. Diabetes 37: 832-837.

34. Schmeichel AM, Schmelzer JD, Low PA (2003) Oxidative injury and apoptosis of dorsal root ganglion neurons in chronic experimental diabetic neuropathy Diabetes 52: 165-171.

35. Stohs SJ (1995) The role of free radicals in toxicity and disease. J Basic Clin Physiol Pharmacol 6: 205-228.

36. Varvarovská J, Racek J, Stozický F, Soucek J, Trefil L, et al. (2003) Parameters of oxidative stress in children with Type 1 diabetes mellitus and their relatives. J Diabetes Complications 17: 7-10.

37. Giugliano D, Ceriello A, Paolisso G (1996) Oxidative stress and diabetic vascular complications. Diabetes Care 19: 257-267.

38. Gürler B, Vural H, Yilmaz N, Oguz H, Satici A, et al. (2000) The role of oxidative stress in diabetic retinopathy. Eye (Lond) 14 Pt 5: 730-735.

39. Jansen J, Karges W, Rink L (2009) Zinc and diabetes--clinical links and molecular mechanisms. J Nutr Biochem 20: 399-417.

40. Faure P, Roussel A, Coudray C, Richard MJ, Halimi S, et al. (1992) Zinc and insulin sensitivity. Biol Trace Elem Res 32: 305-310.

41. Egefjord L, Petersen AB, Rungby J (2010) Zinc, alpha cells and glucagon secretion. Curr Diabetes Rev 6: 52-57.

42. Quesada I, Tudurí E, Ripoll C, Nadal A (2008) Physiology of the pancreatic alpha-cell and glucagon secretion: role in glucose homeostasis and diabetes. J Endocrinol 199: 5-19.

43. Richards-Williams C, Contreras JL, Berecek KH, Schwiebert EM (2008) Extracellular ATP and zinc are co secreted with insulin and activate multiple P2X purinergic receptor channels expressed by islet beta-cells topotentiate insulin secretion. Purinergic Signal 4: 393-405

44. Rungby J (2010) Zinc, zinc transporters and diabetes. Diabetologia 53: 1549 1551

45. Mocchegiani E, Giacconi R, Malavolta M (2008) Zinc signalling and subcellula distribution: emerging targets in type 2 diabetes. Trends Mol Med 14: 419-428.

46. Quarterman J, Mills CF, Humphries WR (1966) The reduced secretion of, and sensitivity to insulin in zinc-deficient rats. Biochem Biophys Res Commun 25 354-358.

47. Meyer JA, Spence DM (2009) A perspective on the role of metals in diabetes: past findings and possible future directions. Metallomics 1: 32-41.

48. Aruoma OI (1998) Free radicals, oxidative stress, and antioxidants in human health and disease. J Am Chem Soc 75: 19.

49. Babu PS, Prabuseenivasan S, Ignacimuthu S (2007) Cinnamaldehyde--a potential antidiabetic agent. Phytomedicine 14: 15-22. 